\title{
Travel Decision and Destination Experiences in the Islands of Caramoan, Philippines: A Visitors' Descriptive Evaluation
}

\author{
Emy S. Lasarte \\ Technology Department, Partido State University- San Jose Campus \\ Del Carmen, San Jose, Camarines Sur, 4423, Philippines
}

\begin{abstract}
An understanding of visitors' travel desires and experiences are vital in two ways- to adjust destination's marketing strategies in order to meet the expectation and demand of the travel market and to ensure sustainability of both physical and social attributes of the place. In this sense, this paper evaluated the travel decision and experiences of visitors in the islands of Caramoan considered as one of the Philippines' uncontaminated and unspoiled natural areas branding it as a "Hidden paradise in the Pacific". Using a questionnaire-based survey administered to onsite visitors in a descriptive method of research, the islands are visited by tourists due to their desire for nature-based and eco-adventure tour. Their experiences with the destination's products, services, and hospitality were generally good with emphasis on the accessibility to natural attractions and religious sites, friendliness of the people service providers, suitable weather condition, and organized excursions. With its continued growth, provision of additional nature-based sports activities, and other tourism products and themes should be designed and developed to create diverse recreational participation. In the same way, improving the frontline tourist facilities as well as tourism frontline services is needed to deliver more meaningful visitor experience.
\end{abstract}

Keywords:- Travel decision; Visitor experience; Tourism destination; Descriptive evaluation.

\section{INTRODUCTION}

An understanding of visitors' travel desires and experiences is at core of the successful tourism destination. It is vital in two ways: First, to adjust destination's marketing strategies, products and services in order to meet the expectation and demand of the travel market, and second to ensure sustainability of both physical and social environment of the place. Hence, it is now recognized that tourism businesses are concerned at evaluating and knowing with what motivates tourists, how they make decisions, how much they enjoy and learn during their vacation experiences, how they interact with the local people and environment, and how they feel about their holidays. While, considering that visitors are the main actors in the travel business, obviously the tourism industry exists to cater to their needs (Goeldner \& Ritchie, 2003) and service providers has to come up with the trends of tourist's consumption to keep its competitiveness. According to Crompton's push and pull model, people travel because they are pushed by their own internal forces or called travel desires that drives a tourist away from home and pulled by the external forces that includes experience and destinations attributes (Dhan, 1997). In the same manner, Quan and Wang (2004) suggesting that tourist experience consist of two dimensions such as, the peak touristic experience and supporting consumer experience. The peak touristic experience is associated to the attractions that form as the major motivation of visitor to visit a particular destination while, the supporting consumer experience are based on the tourism elements, such as accommodation, transportation, food service and other tangible products that are part of the travellers stay during his/her entire journey. As cited by Taylor, Frost, \& Laing (2017), visitor experience is regarded as the primary reason and the essence of the tourism industry. An opportunity to gain experiences is a major catalyst that motivates visitor to leave their homes and travel to other destinations for unusual environment.

Tourism experience usually begins at the departing activities from the tourist generating region and continues at arrival in tourist destination region where full impact occurs in physical settings as a result of their interaction with the local residents, service providers, and participation to leisure activities (Uysal, Woo, \& Singal, 2012). This journey ends-up with the returning activities of the traveler to its origin where recollection takes place as part of the post travel experience. Thus, it is considered as difficult and crucial challenge to destination's managers and administrators to understand and meet visitor expectations and experiences (Taylor et al., 2017) in creating sustained quality and meaningful experience.

Hence, this paper that evaluates the cycle of visitor travel experience in a descriptive manner. Specifically, it assessed the factors affecting the travel decision of visitor to visit particular destination area; determined tourism activities most participated by visitors; and evaluated destination's products, services, and hospitality, as well as, the overall experience in the islands of Caramoan Peninsula, Philippines.

The popularity of the place was gained through Philippine Republic Act (RA) 9445 otherwise known as: "An Act Declaring the Islands of Lahuy, Cotivas, Guinahuan, Luksuhin, Malibagan and Masag, Off the Northeastern Coast of the Municipality of Caramoan, Province of Camarines Sur as National Tourism Zones”. 
This declaration has fuelled local socio-economic development and with its progressive performance for the past few years only signifies a growing competitiveness and development of the area which also calls for sustainable destination management and marketing.

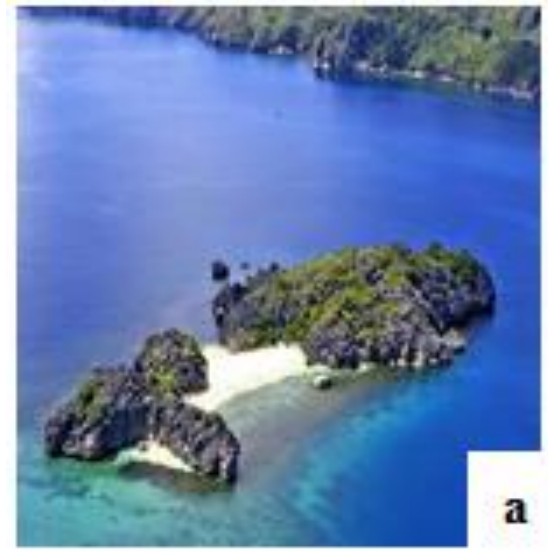

Fig 1:- Primary island attractions: (a) Lahos (vanish) island

(b) Sabitang laya; (c) Matukad island

Source: www.albertthebackpacker.com
Caramoan islands are one of the Philippines' uncontaminated and unspoiled natural areas, thus branding it as a "Hidden paradise in the Pacific" or "The Philippine Best Secret Paradise" (see Figure 1). It is located in the lower eastern part of Camarines Sur in the Bicol region of the Philippine archipelago and is approximately 500 kilometers from the capital Metro Manila.

\section{MATERIALS AND METHODS}

\section{$>$ Research design}

This paper employed a descriptive method of research which is considered common in the leisure and tourism area, for three reasons: the relative newness of the field, the changing nature of phenomena being studied, and the frequent separation between research and action (Veal, 2011). It is also aimed to present and describe the characteristics of the phenomenon being studied (Turk \& Uysal, 2017).

\section{Survey design and data collection}

In order to achieve the purpose of the study, questionnaire-based survey was utilized designed in a selfadministered form that serves as the main gathering tool. This instrument has adopted the online toolkit and resource series for sustainable tourism destination management by Stange et al. (2013) in evaluating the phases of visitors' travel experience developed by Bonaface \& Cooper (2001), which every tourism trip can be thought of as an experience with a series of stages, namely: anticipation, realization, and recollection phases. First, the anticipation phase takes place before the trip in evolves perceptions and expectations about the destination intended to visit. It involves felt need or travel desire, information and evaluation of destinations attributes including products and services which serve as basis of the individual's travel decision and planning (Cooper et al., 1993). Second, the realization phase which considered as the "moment of truth" where the expectation and preparation from the first stage becomes into reality. The destination experience is the goal of the trip and is combined of tourist destination products, services, and hospitality, as well as of both the outward and return journeys. Lastly, the recollection phase which happens after the participation in tourism activities during the journey and stay at the destination visited. It provides the overall evaluation and nostalgic feelings of experience.

Data gathering was conducted to 100 randomly selected on-site local and foreign visitors during the months of March, April, and May 2019 as summer vacation and peak season of the destination.

\section{RESULTS}

This part contained the results of the study. These data covers: visitors' profile; factors affecting the visitor's travel decision; tourism activities participated within the destination area; tourist products, services, and hospitality; and overall visitors' experience post evaluation.

\section{Visitors' profile}

The visitor travel profile in Caramoan have found that $78 \%$ of the visitors were first timers to visit the destination and $22 \%$ of them visited the place repeatedly to which $77.27 \%$ have visited the area 2 to 3 times and $22.72 \%$ or 22 respondents have been to Caramoan 4 to 5 times. 
ISSN No:-2456-2165

\begin{tabular}{|c|c|c|}
\hline Variable & Category & $\%$ \\
\hline \multirow[t]{2}{*}{ Is this your first visit in the area? } & Yes & 78 \\
\hline & No & 22 \\
\hline \multirow[t]{2}{*}{ If NO, how many times, in total, have you visited this area? } & 2 to 3 times & 77.27 \\
\hline & 4 to 5 times & 22.72 \\
\hline \multirow[t]{5}{*}{ Are you travelling } & Alone & 9 \\
\hline & with friends & 25 \\
\hline & with partner & 20 \\
\hline & with family & 28 \\
\hline & with colleagues & 18 \\
\hline \multirow[t]{11}{*}{ In which country do you permanently reside? } & Domestic & 43 \\
\hline & Korea & 3 \\
\hline & USA & 9 \\
\hline & Australia & 8 \\
\hline & Japan & 1 \\
\hline & Canada & 7 \\
\hline & China & 2 \\
\hline & United Kingdom & 4 \\
\hline & Malaysia & 7 \\
\hline & Germany & 13 \\
\hline & Singapore & 3 \\
\hline \multirow[t]{5}{*}{ What was your primary reason of visiting the area? } & Leisure & 74 \\
\hline & Business & 7 \\
\hline & Visiting Friends \& Relatives & 5 \\
\hline & Education & 10 \\
\hline & Volunteerism & 4 \\
\hline \multirow[t]{5}{*}{ How long will you be visiting this area? } & For a day & 15 \\
\hline & 2 to 4 days & 77 \\
\hline & 5 to 10 days & 5 \\
\hline & 11 to 20 days & 2 \\
\hline & More than 21 days & 1 \\
\hline \multirow[t]{9}{*}{ How do you hear about this area? } & Radio & 1 \\
\hline & Television & 2 \\
\hline & Newspaper & 4 \\
\hline & Magazine & 11 \\
\hline & Internet & 21 \\
\hline & Travel Brochure & 3 \\
\hline & Social Media & 24 \\
\hline & Tour Operator & 19 \\
\hline & Word of Mouth & 15 \\
\hline \multirow[t]{6}{*}{ What was your main mode of transportation to this area? } & Personal Car & 14 \\
\hline & Rented Car & 30 \\
\hline & Airplane & $3 \%$ \\
\hline & Tour Bus & 7 \\
\hline & Taxi & 4 \\
\hline & Boat & 42 \\
\hline
\end{tabular}

Table 1:- Visitor travel profile

They were travelling with family with the highest percentage of 28 and only $9 \%$ of the visitors were traveling alone. Most of them were domestic tourists with $43 \%$ and $13 \%$ came from Germany and USA generated 9\%, while Japan was $1 \%$. Their primary reason of visit was for leisure that gained a highest percentage of 74 while few of them visit the area for volunteerism which earned a lowest total of $4 \%$. Most of the visitors stayed in the place for at least 2 to 4 days at $77 \%$ and only $1 \%$ of them stayed for more than 21 days in the destination. The highest means of their information to the tourist destination was through social media which accounted $24 \%$ of responses and only $1 \%$ of them heard the place through radio. Furthermore, the main mode of transportation of visitors to the area was by water through boat that gained a total of $42 \%$, followed by the rented car with a total of $30 \%$ and only $3 \%$ of them were travelling by air. 
Factors affecting travel decision

\begin{tabular}{|c|c|c|}
\hline Factors & Mean & Interpretation \\
\hline Good weather condition & 3.90 & Very Important \\
\hline $\begin{array}{l}\text { Quality and natural scenery and } \\
\text { landscapes/environment }\end{array}$ & 3.35 & Very Important \\
\hline Opportunity to see wildlife & 3.80 & Very Important \\
\hline $\begin{array}{l}\text { Visits to parks and other pristine } \\
\text { natural areas }\end{array}$ & 3.85 & Very Important \\
\hline $\begin{array}{c}\text { Opportunity to stay in pristine } \\
\text { natural environment }\end{array}$ & 3.80 & Very In \\
\hline $\begin{array}{c}\text { Desire to learn about other } \\
\text { cultures, their ways of life, and } \\
\text { heritage }\end{array}$ & 2.50 & $\operatorname{Imp}$ \\
\hline $\begin{array}{r}\text { Participation in } n \\
\text { religious }\end{array}$ & 2.20 & $\begin{array}{l}\text { Not Very } \\
\text { Important }\end{array}$ \\
\hline $\begin{array}{c}\text { Opportunity to } \mathrm{v} \\
\text { or traditional } \\
\end{array}$ & 2.00 & $\begin{array}{l}\text { Not Very } \\
\text { Important }\end{array}$ \\
\hline $\begin{array}{r}\text { Opportunities } \mathrm{t} \\
\text { traditional } \mathrm{w}\end{array}$ & 1.80 & $\begin{array}{l}\text { Not Very } \\
\text { Important }\end{array}$ \\
\hline $\begin{array}{l}\text { Opportunities for learning about } \\
\text { and experiencing natural and } \\
\text { cultural attractions }\end{array}$ & 3.35 & Very Important \\
\hline $\begin{array}{c}\text { Opportunities for } \\
\text { adventure/sports activities }\end{array}$ & 3.75 & Very Important \\
\hline Good prices for quality received & 3.85 & Very Important \\
\hline $\begin{array}{c}\text { Good local transportation } \\
\text { system }\end{array}$ & 3.55 & Very Important \\
\hline $\begin{array}{l}\text { Recommendations from a } \\
\text { friend/book }\end{array}$ & 2.75 & Important \\
\hline Facilities for children & 3.10 & Important \\
\hline Accessibility & 3.95 & Very Important \\
\hline Safety and security & 3.90 & Very Important \\
\hline $\begin{array}{c}\text { Interest in business investment } \\
\text { in visited area }\end{array}$ & 2.48 & $\begin{array}{l}\text { Not Very } \\
\text { Important }\end{array}$ \\
\hline
\end{tabular}

Table 2:- Factors affecting the travel decision of visitors to visit Caramoan

The factors affecting the travel decision of visitors to visit Caramoan are presented in table 2. It was clearly recognized that the accessibility of the place is very important for them which earned a highest mean of 3.95. Likewise, the safety and security and good weather condition were also very important factors to the travel decision of visitors that received a total mean of 3.90 .

The good prices for quality received and chance to visit to parks and other pristine natural areas are perceived very important which gained a mean of 3.85. Furthermore, opportunities to see wildlife and stay in pristine natural environment were added very important factors to the visitors that affect their travel decision with a mean of 3.80 . The mean of 3.75 interpreted as very important was attributed to opportunities for adventure/ sports activities. It is followed by the good local transportation system of 3.55 mean and opportunities for learning about and experiencing natural and cultural attractions with a total of 3.35 which were both very important factors in the decision making of the visitors. Another attributes that were rated important factors affecting the travel decision of the visitors with their corresponding mean were facilities for children (3.10); recommendations from a friend/book (2.75); and the desire to learn about other cultures, their ways of life, and heritage (2.50).

However, the factors such as interest in business investment (2.48); participation in major cultural or religious events (2.20), opportunity to visit indigenous or traditional communities (2.00); and opportunities to experience traditional ways of life $(1.80)$ were rated and perceived as not very important factors affecting the travel decision of visitors in the destination.

\section{Participated recreational activities}

The most participated tourism activities by visitors in the tourist destination area were ranked according to the responses from the visitors.

\begin{tabular}{|c|c|c|}
\hline Tourism Activities & \% & Rank \\
\hline Island hopping & 98 & 1 \\
\hline Swimming/scuba diving & 97 & 2 \\
\hline Spelunking/caving & 81 & 3 \\
\hline Kayaking & 60 & 4 \\
\hline Souvenir Shopping & 53 & 5 \\
\hline Water paddling & 42 & 6 \\
\hline Hiking/trekking & 40 & 7 \\
\hline Visiting historical & 30 & 8 \\
places/landmarks/cultural heritage & & \\
\hline sites & & 9 \\
\hline Climbing & 26 & 10 \\
\hline Biking & 18 & 11 \\
\hline Visiting villages/small towns & 13 & 12 \\
\hline Nightlife activities & 11 & 13 \\
\hline Wildlife viewing & 10 & 14 \\
\hline Religious/pilgrim & 3 & 15 \\
\hline Attending art or music performances & & 15 \\
\hline Tabled
\end{tabular}

Table 3:- Recreational activities participated in the destination

Among the fifteen activities available in Caramoan, island hopping dominates the recreational activities which gathered a total of $98 \%$; followed by the swimming/scuba diving of 97\%; spelunking, 81\%; kayaking, $60 \%$; and souvenir shopping which ranked number 5 with $53 \%$. While, attending to art or music performances considered least participated of $3 \%$ responses.

\section{$>$ Destination products, services, and hospitality experience}

The experience of visitors in destination's tourism products, services, and hospitality are shown in table 4 . It is clearly noted that accessibility to natural attractions (4.50); accessibility to religious sites (4.40); friendliness of the people service providers (4.25); weather (4.25); and organized excursions (4.20) were excellent qualities of the tourist destinations according from the surveyed visitors in the area. The tour guides were very good at 4.15 mean, followed by the rating of 4.10 which signifies very good in terms of local cuisine/drinks. 


\begin{tabular}{|c|c|c|}
\hline $\begin{array}{c}\text { Products, Services and } \\
\text { Hospitality }\end{array}$ & Mean & Interpretation \\
\hline $\begin{array}{l}\text { Services at the seaports and } \\
\text { terminals }\end{array}$ & 2.90 & Good \\
\hline $\begin{array}{l}\text { Maintenance and convenience of } \\
\text { the sea port }\end{array}$ & 2.60 & Good \\
\hline Personal safety & 3.20 & Good \\
\hline $\begin{array}{l}\text { Friendliness of the people } \\
\text { service providers }\end{array}$ & 4.25 & Excellent \\
\hline Acceptance of local residents & 4.10 & Very Good \\
\hline Tourist-host interactions & 3.50 & Very Good \\
\hline $\begin{array}{l}\text { Explanation and convenience of } \\
\text { the customs }\end{array}$ & 2.75 & Good \\
\hline Local cuisine/drinks & 4.10 & Very Good \\
\hline $\begin{array}{l}\text { Accessibility to cultural heritage } \\
\text { sites }\end{array}$ & 4.00 & Very Good \\
\hline $\begin{array}{l}\text { Accessibility to natural } \\
\text { attractions }\end{array}$ & 4.50 & Excellent \\
\hline Accessibility to religious sites & 4.40 & Excellent \\
\hline $\begin{array}{l}\text { Interpretation of natural/cultural } \\
\text { heritage sites }\end{array}$ & 3.00 & Good \\
\hline $\begin{array}{l}\text { Diversity of adventure/athletic } \\
\text { activities }\end{array}$ & 3.38 & Good \\
\hline $\begin{array}{l}\text { Availability of equipment for } \\
\text { adventure activities }\end{array}$ & 2.75 & Good \\
\hline Visitor centers & 2.60 & Good \\
\hline Organized excursions & 4.20 & Excellent \\
\hline $\begin{array}{c}\text { Degree of knowledge of foreign } \\
\text { languages from the service } \\
\text { personnel }\end{array}$ & 2.60 & Good \\
\hline Police visibility & 2.50 & Fair \\
\hline Weather & 4.25 & Excellent \\
\hline Facilities for children & 2.59 & Fair \\
\hline Shopping opportunities & 1.60 & Poor \\
\hline $\begin{array}{l}\text { Telecommunications facilities } \\
\text { and internet }\end{array}$ & 2.50 & Fair \\
\hline $\begin{array}{l}\text { Convenience and access to local } \\
\text { transport }\end{array}$ & 2.75 & Good \\
\hline Entertainment/nightlife & 1.90 & Fair \\
\hline $\begin{array}{c}\text { Presence/availability of } \\
\text { automated-teller-machines } \\
\text { (ATM)/commercial banks }\end{array}$ & 2.50 & Fair \\
\hline $\begin{array}{l}\text { Accommodation/lodging } \\
\text { facilities }\end{array}$ & 3.45 & Very Good \\
\hline Food services facilities & 2.90 & Good \\
\hline Hospital/medical centers & 2.50 & Fair \\
\hline Tour guide & 4.15 & Very Good \\
\hline Hotel staff & 4.00 & Very Good \\
\hline Water and electricity & 2.70 & Good \\
\hline
\end{tabular}

Table 4:- Destination products, services, and hospitality experience

Other very good responses were given to acceptance of local residents that received a 4.10 mean and accessibility to cultural heritage sites and hotel staff which garnered a total of 4.00 individually. In addition, visitors had experienced very good tourist-host interactions in the destination with a value of 3.50; likewise the accommodation/lodging facilities were rated 3.45 and interpreted as very good.
Findings also showed that the following ratings were observed: the diversity of adventure/athletic activities (3.38); personal safety (3.20); interpretation of natural/cultural heritage sites (3.00); and services at the seaports and terminals and food services facilities (2.90) were experienced well by the visitors. Similarly, on the availability of equipment; explanation and convenience of the customs; and convenience and access to local transport were experienced good for a mean of 2.75 respectively by visitors as well as with the supply of water and electricity which resulted in 2.70 mean and given with the same interpretation. Furthermore, a mean of 2.60 as good were attributed to maintenance and convenience of the sea port, degree of knowledge of foreign languages from the service personnel, and visitors centers.

Meanwhile, fair ratings were given to: police visibility; telecommunications facilities and internet; presence/ availability of automated-teller-machines (ATM)/commercial banks; and hospital medical center which gained a 2.50 mean respectively. Relatively fair ratings were given to the facilities for children with 2.59 and entertainment/nightlife with 1.90 mean. The very least was the poor experience by the visitors to the shopping opportunities in the destination which earned a value of 1.60 .

\section{$>$ Overall visitors' travel experience}

Table 5 reveals the overall post-evaluation of visitors in the destination area. Majority of the respondents answered YES and that they will recommend visiting the place to their friends/relatives.

\begin{tabular}{|c|c|c|c|}
\hline Variable & Category & $f$ & $\%$ \\
\hline \multirow{2}{*}{$\begin{array}{l}\text { Would you recommend } \\
\text { that friend/relatives of } \\
\text { yours visit this area? }\end{array}$} & Yes & 83 & 83 \\
\hline & $\mathrm{No}$ & 17 & 17 \\
\hline
\end{tabular}

Table 5:- Overall visitors' travel experience

\section{CONCLUSION AND RECOMMENDATIONS}

The desires for nature and eco-adventure tour as well as the quality of service and facilities in the destination are considered main factors that influence the visitor's travel decision to visit Caramoan. Their actual experiences in the place was found to be excellent along with the accessibility to natural attractions and religious sites, friendliness of the service providers, suitable weather condition, and organized excursions. While, in terms of police visibility, telecommunications facilities and internet availability, presence of automated-teller-machines (ATM)/commercial banks, hospital medical center, facilities for children, and entertainment/nightlife were experienced fair by the visitors during their stay. Similarly, poor rating was attributed to shopping opportunities. Generally, the overall postevaluation of visitors in Caramoan to recommend visiting the place to their friends/relatives were majority yes. According to Jagger \& Halpenny (2012), their interaction with the place creates the visitors experience, and high quality of visitors experience is a fulfilled outcome in participation to recreational activities. Hence, tourism in 
these settings is focused on a wide range of sensory and intellectual situations which combine to form the vacation experience (Cochrane, 2006) and tourism managers have to understand reasons why people are traveling and the purpose of their visit, likewise understand the factors that influence visitors' experiences and take a necessary action immediately. Moreover, it is suitable for destination area managers to understand what specific natural, social and managerial elements are necessary in facilitating visitor experiences (McCool, 2006).

With these significant findings, the following recommendations were developed as a reference and basis for appropriate actions: (a) further create and develop additional nature-based sports activities to provide a widerange of recreational participation for a diverse visitors' experience; (b) aside from the nature-based tourism and eco-adventure tours/activities, consider developing and designing other tourism products/themes that will attract and cater to other market/group of visitors such as pilgrim/religious and cultural-heritage tours; (c) improve the frontline tourist facilities such as: seaports and terminals, food service facilities, visitor centres, and automated-teller machines/commercial banks; as well as improve tourism frontline services namely: interpretation of natural/cultural heritage sites, knowledge of foreign languages from the service personnel, police visibility, and service supply of water and electricity; (d) consider building/establishing additional tourism facilities like special playground/recreational facilities for the children, shopping centres, and entertainment/nightlife venues; and (e) create/design integrated marketing communication plan and improve existing marketing campaigns to generate more foreign visitors.

\section{ACKNOWLEDMENT}

The author acknowledges its funding institution - the Partido State University for technical and financial supports. Likewise, to her colleagues and good friends $\mathrm{Mr}$. Niño Rebuya and Engr. Kier Gasga for their company and direct valuable inputs during the conduct and development of the study.

\section{REFERENCES}

[1]. Goeldner, Charles R., \& J.R. B. Ritchie (2003). Tourism Principles, Practices, Philosophies, $9^{\text {th }}$ edition. USA: John Wiley \& Sons.

[2]. Dan, M. S. (1997). Anomie, Ego-Enhancement and Tourism. Annals of Tourism Research IV (4): 184194.

[3]. Quan, S. \& Wang, N. (2004). Towards a structural model of the tourist experience: an illustration from food experiences in tourism. Tourism Management 25(3), p.297-305.

[4]. Taylor P., Frost W., \& Laing, J. (2017). Meeting the Challenge of Managing Visitor Experiences at Tourism Attractions. Visitor Management in Tourism Destinations, p.22
[5]. Uysal, F., Woo, E., \& Singal, M. (2012). The Tourist Area Life Cycle (TALC) and Its Effect on the Qualityof-Life (QOL) of Destination Community, Handbook of Tourism and Quality-of-Life research: Enhancing the Lives of Tourists and Residents of Hosts Communities, International Handbooks of Quality of Life, p.423.

[6]. Veal, A.J. (2001). Research Methods for Leisure and Tourism: A Practical Guide. Fourth Edition. Pearson Education Limited. Edinburgh Gate, Harlow, England.

[7]. [7].Turk, E.S., \& Uysal M. (2017). Research Methods for Leisure, Recreation and Tourism, $2^{\text {nd }}$ Edition. CAB International, p. 15

[8]. Stange, J., et al. (2013). Tourism Destination Management, Achieving Sustainable and Competitiveness- Sustainable Tourism: International Cooperation for Development, Online Toolkit and Resource Series. International Institute for Tourism Studies- The George Washington University, p. 47-54.

[9]. Boniface, B. \& Cooper, C. (2001). Worldwide Destinations: The Geography of Travel and Tourism, Hinemann, London.

[10]. Cooper, Chris et al. (1993). Tourism: Principles and Practice. UK: Pitman Publishing.

[11]. Jagger, E. \& Halpenny, A.(2012). Supporting the CBD Aichi Biodiversity Targets through Park Tourism: A Case Study of Parks Canada's Visitor Experience Programme. Vol. 18(2).

[12]. Cochrane, J. (2006). A typology of tourists to protected areas. Protected Areas Program. The Visitor Experience Challenge. Vol. 16(2)

[13]. McCool, S.F. (2006). Managing for Visitors Experiences in Protected Areas: Promising 'Opportunities \& Fundamental Challenges. 